THURSDAY, FEBRUARY 7, 1884

\section{JURASSIC ROCKS UNDER LONDON}

$\mathrm{O}$

$\mathrm{N}$ two previous occasions ${ }^{1}$ the attention of the readers of NATURE has been directed to the facts which have been revealed by deep borings in search of water under London. In the first of these communications it was shown how completely the predictions of geologists, as to the nature, succession, and thicknesses of the different strata under London had been verified; and in the second the question of the possibility of finding workable coal-seams beneath the metropolitan area was discussed at some length.

Quite recently, however, a new boring has been put down within the London Basin, which has made known so many new facts of surpassing interest to the geologist, and has at the same time furnished them with new data, tending to modify their former conclusions on some important problems, that it may be well to recur to the subject in the pages of this journal, and to give a short account of these remarkable discoveries.

The growing wants of the town of Richmond in Surrey have caused the local authorities of that place to seek an augmentation of their water-supply by carrying to a much greater depth a well which had some years ago been put down into the Chalk. This has been done by boring by Mather and Platt's flat-rope system, the work being done under the direction of Mr. C. Homersham, C.E., and at the present time a depth of 1308 feet has been attained. Not only is this well actually a few feet deeper than the famous well at Kentish Town, which was carried 1302 feet beneath the surface, but, commencing as it does near the level of the Thames, it reaches, reckoning from the Ordnance datum line, a level more than I 50 feet lower than that of any well hitherto sunk within the London Basin.

Up to the present time only insignificant supplies of water have been obtained, but it is to be hoped that as the work is carried on this spirited enterprise may meet with the success it so well deserves. To the student of London geology it has already afforded a number of facts of wonderful novelty and interest.

The succession of strata found in this well was as follows :-

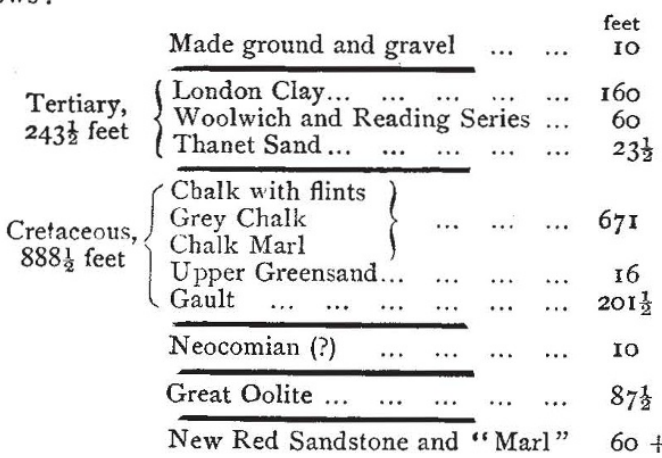

The lines indicate unconformable breaks in the series of strata, and the lapse of enormous periods of time between the deposition of the beds which they separate.

Down to the base of the Gault the order and thick-

${ }^{x}$ See NAtUre, vol. xvi. p. 2, and vol. xxv. pp. 3ir, $36 \mathrm{r}$.

VOL. XXIX.-NO. 74 nesses of the several formations was exactly what would be predicted by any geologist conversant with the details of London geology. Some very interesting facts concerning the divisions of the Chalk strata under London have, however, been made out for the first time by the study of the admirable series of "cores" brought to the surface during these boring operations.

But it is with respect to the strata found lying beneath the Gault that the greatest amount of interest has been excited among geologists.

The Gault clay has at its base the usual band of phosphatic nodules, the so-called "coprolites," and beneath this was found a series of beds, ten feet in thickness, the nature of which is peculiar, while their age is somewhat problematical.

These beds appear in fact to consist of materials derived from the wearing away of the rocks on which they repose, but include fragments of other rocks evidently brought from a distance. They contain many "derived fossils," greatly fractured and waterworn, but very few of its organic remains are of the age of the deposit itself, and serve to fix its geological age. From a consideration of the whole of the evidence in this case, however, this series of rocks, ten feet in thickness, may be referred with considerable probability to some part of the Neocomian period. Unfortunately the typical Lower Greensand was wholly wanting, and the expected supplies of water from this source were therefore missed.

But immediately beneath this peculiar and somewhat puzzling stratum, deposits of great interest to the geologist were encountered. They consisted of thick beds of oolitic limestone, with some subordinate beds of clay, fuller's earth, and sandstone, the whole having a thickness of $87 \frac{1}{2}$ feet. A few fossils, for the most part very imperfect, were found in the limestone, but one of the clay bands, when carefully washed, proved to be veritable "El Dorado" to the palæontologist. It was seen to be crowded with specimens of Brachiopods, Bryozoa, Echinoderms, and other organisms, all of them in the most exquisite state of preservation. It is evident that these organisms which flourished upon the floor of the sea were killed and overwhelmed by a sudden influx of muddy sediment. The species found in this interesting bed of clay, which is only six inches in thickness, are similar to those which occur in the Bradford Clay of Wiltshire, and the Calcaire de Ranville of Normandy. It is evident, therefore, that the deposit which contains them is of the age of the Great Oolite. These great oolite strata are found to rest directly on the Trias,- the Inferior Oolite, Lias, and Rhætic being absent.

Now no strata of the age of the Lower Oolites were before known to exist under the London Basin, though it is but fair to remember that Mr. Godwin-Austen, in his celebrated essay on the probable existence of coal under London, distinctly pointed out the possibility of the existence of such deposits.

In the boring which in the year 1878 was put down at Messrs. Meux's Brewery in the Tottenham Court Road some anomalous strata about 64 feet in thickness were found lying between the Gault Clay and the Devonian rocks in which that boring terminated. From some obscure casts of fossils detected in these beds, they were, at the time of their discovery, referred to the Neocomian. 
But a careful re-examination of the question shows that, like the beds above described at Richmond, they certainly belong to the Great Oolite, though they were deposited under shallower water conditions than their equivalents at the latter place, and were perhaps, in part at least, of estuarine origin.

The Trias is another formation which has not hitherto been certainly detected under London. It is true that some geologists think that the rocks reached in the Kentish Town and Crossness borings belong to that formation, but this identification is disputed by some very eminent authorities. Although no fossils have been found in the red and variegated strata of the Richmond boring, yet their mineral characters are such as to leave scarcely any room for doubt that they belong to some part of the "Poikilitic" or New Red Sandstone system. They consist of coarse and fine grained sandstones, of en exhibiting false-bedding, which alternate with red and variegated clays or "marls." It will be of great interest to geologists if it can be determined upon what member of the Palæozoic rocks these Triassic strata repose.

The result of the deep boring at Richmond is to show that while the water-bearing strata of the Lower Greensand do not extend so far northward as Richmond, other unexpected deposits do exist beneath that town. During portions of the Triassic and Jurassic periods the great Palæozoic ridge, stretching between the Mendips and the Ardennes, was in part or wholly submerged, and thus we find deposits of these ages along its flanks. The relation of the Great Oolite under the central and southern metropolitan district are strikingly similar to those of the Lower Oolite in the Boulonnais. Taking into consideration the proved thickness of the Upper and Middle Oolites in the "Wealden boring" at Battle, we most be prepared to find the Palæozoic axis, with its possible coal-beds, at a considerably greater depth beneath the surface in the southern half of the London Basin than had hitherto been anticipated.

Although no beds of Middle Oolite age have as yet been found under the London Basin, yet, that strata of this period were originally deposited there, we have a very interesting and curious proof. Among the beds of the Lower Greensand of the North Downs, between Sevenoaks and Farnham, we often find deposits consisting of such coarse materi 1 ls as almo-t to merit the name of conglomerates. These consist in great part of waterworn fragments of hard and sub-crystalline rocks, evidently derived from the great Palæozoic ridge lying to the north. Mingled with these pebbles are great numbers of excessively eroded but sometimes still recognisable fossils evidently washed out of beds of Lower and Middle Oolite age. The former, as we have just showed, have now been detected under London; but such is not the case with the latter, which mav not improbably have been wholly removed by denudation before the deposition of the Cretaceous strata.

In one of the articles referred to at the commencement of this notice, it was pointed out that not only might coal be found at workable depths under London, but that, when discovered, this coal would prubably be of the anthracite variety. Now although no beds of coal have hitherto been found in place beneath the metropolis, yet the Richmond boring has yielded striking and un- mistakable evidence as to the presence and nature of the coal-seams under the London Basin. In several of the deposits pebbles of coal-measure sandstone with fragments of anthracite have been detected. From this interesting fact it may be justly inferred that while the beds in question were being deposited on the flanks of the old Palæozoic ridge, portions of that ridge consisting of Carboniferous strata and containing seams of anthracite rose above the level of the sea and yielded the fragments mentioned. That the source of these fragments was not very distant may be inferred from the brittleness of anthracite, which certainly could not have travelled far. Thus at last the prediction of geologists has been verified, and coal has been found under London, though as yet unfortunately not in situ.

JOHN W. JUDD

\section{MENTAL EVOLUTION IN ANIMALS}

Mental Evolution in Animals. By G. J. Romanes, M.A., LL.D., F.R.S., \&c. With a Posthumous Essay on Instinct, by Charles Darwin. (London: C. Kegan Paul \& Co., I 883.)

I $\mathrm{N}$ the present volume Mr. Romanes redeems a part 1 of the promise which he gave us in his "Animal Intelligence." He traces in its main outlines the development of mind in the lower animals. The other part of the promise, to follow the course of mental development in man, will be fulfilled in another work. We think it well that the author has thus divided his task. Each division is of sufficient magnitude to require a separate volume; and though as an evolutionist Mr. Romanes would of course maintain the continuity and identity of the process of mental evolution from its first obscure manifestations in the lower grades of animals up to its highest present point of attainment in civilised man, he would probably allow that the two stages of the process, the sub-human and the human, are sufficiently differenced by the difference in the degree of complexity of the factors involved. To this it may be added that the detailed study of each of these two stages of mental life requires a body of knowledge of its own, a special modification of psychological method, and a particular kind of psychological interest.

In the present work the author has to face a much more difficult task than that which he undertook in his earlier volume. This no doubt had its difficulties. For in what we call the "observation" of mind, whether in our fellow-men or in the lower animals, a process of inference is involved; and when the action to be psychologically interpreted is far removed from the ordinary types of human action, this process is one of peculiar difficulty. But in the earlier work inference or interpretation played a subordinate part. Here, however, it becomes the main problem. In order to connect the facts ascertained and to present a systematic view of mental life as a whole, we must have clear notions respecting the nature of mind in general, as well as of its several phases, which we mark off by the names of the faculties perception, imagination, \&c. It is not too much to say that in carrying out the task of tracing the evolution of mind in the lower region an inquirer needs to combine the special aptitudes of a naturalist with those of a psychologist. 